\title{
Factors that May Lead on the Non-renewal of Certified Organic Product According to Organic Producers in Brazil ${ }^{1,2}$
}

\author{
Andréa Rossi Scalco ${ }^{3}$, Sandra Cristina de Oliveira ${ }^{4}$, \\ Giuliana Santini Pigatto ${ }^{5}$ and Juliana Cobre ${ }^{6}$
}

\begin{abstract}
The regulatory process of the organic sector in Brazil began in 1999 and has gone through several changes, culminating in the Decree-Law of December 2007, which established rules for the production and trading of organic products in Brazil. In such Decree, the certification has become a compulsory requirement for production and trading of such products, whose rules governing their obtaining follow rigorous controls standards. As the certification process of organic products is recent and there is a lack of studies carried on this subject, this study will contribute to fill the existing gap in the international literature, mainly national about this topic, once that aimed to identify factors that influence the possibility of non-renewal of organic production certificate, according to the perception of certified producers in Brazil. Through this effort, this research should contribute to wider adherence and maintenance of the producer in the certified system or, at least, proposals for further works. A total of 200 producers from several Brazilian states participated in this study, and data analysis was performed using descriptive statistics and, later, exploratory factor analysis. The results achieved holds that the determining factors to the non-renewal of the certificate involve variables related to transactions among operators, organization of the supply chain and to the regulations. Furthermore, to overcome the challenges imposed to rural producers, one of the proposals is for greater effective actions from representative industry entities of the sector in aspects that are related to the certification process.
\end{abstract}

Key-words: certification, organic producers, exploratory factor analysis.

1. Data de submissão: 5 de fevereiro de 2016. Data de aceite: 21 de maio de 2017.

2. The authors would like to thank the Conselho Nacional de Desenvolvimento Científico e Tecnológico (CNPq) for funding the research project developed in 2012-2014 and Fundação de Amparo à Pesquisa do Estado de São Paulo (Fapesp).

3. Faculdade de Ciências e Engenharia - Universidade Estadual Paulista, Tupã, São Paulo, Brasil. E-mail: andrea@tupa.unesp.br

4. Faculdade de Ciências e Engenharia - Universidade Estadual Paulista, Tupã, São Paulo, Brasil. E-mail: sandra@tupa.unesp.br

5. Faculdade de Ciências e Engenharia - Universidade Estadual Paulista, Tupã, São Paulo, Brasil. E-mail: giuliana@tupa.unesp.br

6. Instituto de Ciências Matemáticas e de Computação, Universidade de São Paulo, São Carlos, São Paulo, Brasil. E-mail: jucobre@gmail.com 
Resumo: O processo de regulamentação do setor de orgânicos no Brasil se iniciou em 1999 e passou por várias mudanças, culminando no Decreto-lei de dezembro de 2007, que estabeleceu regras para produção e comercialização de produtos orgânicos no Brasil. Em tal decreto, a certificação se tornou requisito compulsório para produção e comercialização de tais produtos, cujas regras para sua obtenção seguem padrões rigorosos de controle. Sendo recente o processo de certificação de produtos orgânicos, esta pesquisa vem contribuir à literatura internacional e, principalmente, nacional, sobre este tema, com o objetivo de identificar os fatores que influenciam a possibilidade de não renovação do certificado de produção de orgânicos, segundo a percepção de produtores certificados do Brasil, e assim propor ações que possam contribuir para adesão e manutenção no sistema certificado. Participaram dessa pesquisa 200 produtores de vários estados brasileiros, e a análise dos dados foi realizada por meio de estatística descritiva e, posteriormente, análise fatorial exploratória. Os resultados apontaram que os fatores considerados determinantes para a não renovação do certificado envolvem variáveis relacionadas às transações entre os agentes, à organização da cadeia produtiva e à regulamentação. Para superar os desafios impostos aos produtores rurais, uma das propostas é que haja maior efetividade das ações das entidades de classe representativas do setor no que se refere aos aspectos relacionados ao processo de certificação.

Palavras-chaves: certificação, produtores orgânicos, análise fatorial exploratória.

Classificação JEL: Q1, Q13.

DOI: http://dx.doi.org/10.1590/1234-56781806-94790550303

\section{Introduction}

Alternative production systems have been developed since the second half of the $20^{\text {th }}$ century, including the organic production system that defends alternative production practices which differentiate themselves from the conventional production systems. The National Research Council and also the United States Department of Agriculture (USDA) have been developing studies related to rural production with reduced or even without the use of chemical inputs since the 1980s. Then, in 1990, through USDA, that "Facta" was established, which is an American agricultural law aiming to promote development actions focused on organic production with a sustainable ecological model tendency (SOUZA and ALCANTARA, 2003).

In Brazil, in parallel to the American actions, the cultivation of organic products were promoted by religious and ethical movements and started, even timidly, in the 1980s. In 1999 this sector was regulated by Normative Instruction no 007 of 05/17/1999 (BRASIL, 1999); in 2003, through Law 10,831, the guidelines of production, classification, processing, bottling, distribution, identification and quality certification for organic products of animal or plant origin were established (BRASIL, 2003). And then, in December 2007, through the Decree-Law 6,323 (BRASIL, 2007), the whole regularization procedure of this sector had a major leap as it put important specifications to the regulation of organic sector, becoming mandatory the organic certification in establishments that produced and traded organic products. Thereafter, all data from producers of organic agriculture should be registered at Ministry of Agriculture, Livestock and Supply (MAPA) through their certifying agencies. Nowadays there is a public database available on MAPA website, which contains details of organic producers such as area size, type of certification and cultures. The mandatory certification for producers and distributors facilities also had been established in this decree (Law 6,323 of December 2007) with a 2 years term to adequacy of the facilities. However, the Decree 7,048 of December 2009 (BRASIL 2009) changed the deadline for 1 more year of adequacy.

Since the certification of the organic production systems became compulsory from 2011, some national researches, as Brito (2016), Muñoz et al. (2016) e Niederle (2014), contributed to the understanding of the theme pointing some differences between the conventional production system and the organic one, including some difficulties that the Brazilian producers have faced in the transition process when rules were established. However, in national and international scopes, there is still a need to progress in studies related to non-adherence and the loss or dropout of the certificate, particularly the organic product 
certificate in rural properties. Then, this research aims to identify the factors that influence the non-renewal of the organic production certificate, as perceived from certified producers in Brazil ${ }^{7}$, and to propose actions that may contribute to an increase adherence to the certified system.

The other topics of this paper are organized as follows. First the organic certification system including limiting issues to the certification are reported. In sequence, the materials and methods used in this research are described and then the results and discussion are presented. Finally the conclusion and proposes actions to reducing uncertainties regarding certification finalize the paper.

\section{The organic certification system}

In accordance with Art. 1 of Law 10,831 of 12/23/2003 (BRASIL, 2003), which deals with pertinent activities to the development of organic agriculture, it is considered organic system of agricultural production:

"any system in which specific techniques are employed by optimizing the use of natural and socioeconomic available resources, and respect for cultural integrity of rural communities, whose objectives are economical and environmental sustainability, maximization of social benefits and minimization of nonrenewable energy dependence, applying, whenever possible, cultural, biological and mechanical methods, in contrast to the use of synthetic materials, phasing out the use of genetically modified organisms and ionizing radiation, in any stage of production, processing, storage, distribution, commercialization and environmental protection" (BRASIL, 2003).

In order for the producer to be able to trade organic products it is required the emission of a stamp, carried out by Mapa, which aims to ensure to the consumer that the organic product is indeed organic. The

7. The research was directed to certified and uncertified producers (i.e., who no longer have the certificate). However, due to difficulties to obtain contacts of the uncertified producers, the research remained to certified producers. emission of this stamp, also known as organic certified production, is done by the compliance assessment. The compliance assessment is the "demonstration that specified requirements relating to a product, process, system, person or entity are attended" (ABNT NBR ISO/IEC 17000:2005, p. 1, 2008). The proof, i.e., the warranty that a product, process, system, person or entity follows given specifications merely through a systemic compliance assessment. According to Inmetro cited by ABNT (2008), "the systemic compliance assessment is a standard process, with pre-established rules, properly monitored and evaluated, in order to provide appropriate degree of confidence that a product, process or service, or even a professional, meets the prerequisites set by rules or regulations with the lowest possible cost to society" (INMETRO 2007, p. 8 cited by ABNT 2008).

The production and trading of organic products, according to Decree-Law 6,323 of December 2007, foresee three instruments for quality assurance of organic production: third-party certification (also known as certification by audit), participative assurance systems and social control for direct sales without a certification.

Third-party certification is a compliance assessment process carried out by a certifying authority that does not have any link with whom will be certified. In this way is assured, formally, that a product, process or service complies with prerequisites established by the issue of a certificate (SOUZA, 2011). Concerning to the organic sector, the third-party certification can be conducted by public or private certifying agencies accredited by MAPA, which uses international criteria and procedures that are recognized by the International Foudation for Organic Agriculture (Ifoam). This kind of certification can be done individually or in groups, which latter type specifies a minimum and maximum limit of members in the producer group to be certified.

As a second certification instrument there are the participative assurance systems (PAS). This system is characterized by collective responsibility of their members in obtaining the control mechanism; however, is worth noting that PAS must have a Participatory Organization for Compliance Assessment (Poca), legally constituted (being a legal entity) and accredited at Mapa.

The structure of PAS consists of Members from the System and from the Poca. Members from the 
System are individuals or legal entities classified as suppliers, whether producers, distributors, traders and carriers; and contributors (consumers, technicians, public or private organizations, non-governmental organizations and class representatives). The role of members is to contribute to credibility of the system and to assume joint liability with regard to noncompliance of the rules for organic production by one of their members. In contrast, Poca must be legally constituted and is responsible to evaluate, to include producers on SisOrg register and to give permission for members to use the stamp (MAPA, 2011). The Poca needs to be structured by an Evaluation Commission and a Council of Appeals formed by representative members of the PAS, that should formally request their inclusion to the Poca. The Evaluation Commission has the task of verifying compliances and the Council of Appeals is responsible for processing of the appeals and claims. The Poca should be accredited at the Ministry of Agriculture, Livestock and Supply, through the Service of Policy and Agricultural Development.

The third control mechanism is the social control that does not generate a certificate of organic production system (SisOrg stamp), however, offers to producers a certificate which says the product that the same is trading is organic. This kind of control should be used to producers who perform direct sale to the final consumer, mainly in organic products fairs and small establishments intending to sell organic products directly from the farmers to the consumers. To obtain such certificate is required that the producer, besides meeting the requirements in which it considers as a family farmer, must be associated with a Social Control Organization (SCO) and be registered at Mapa.

The decision on which mechanism to use to certify the organic production system will depend on the extent of marketing channels, the type of marketing channel, costs incurred in certification, understanding of regulations and involvement in producer associations or cooperatives.

\subsection{Limiting factors related to the certification in the organic farming systems}

Flaten et al. (2005) used linear regression analysis to verify the characteristics of producers who have abandoned the organic production in Norway, indicating some evidence that the abandonment of the certificate of these producers are related to factors such as "sector regulation" and "economic reasons". In another research, Pietola and Lansink (2001) identified "the price for joining the certificate" and "subsidies fees" as reasons not to convert from conventional to organic system.

MacInnis (2004) looked at the effect of transaction costs on the choice of trading channels for organic and conventional farmers in the United States. The findings suggest that the "lack of trading channels for organic products" can be a significant barrier to entry into organic agriculture.

Veldstra, Alexander and Marshall (2014) analyzed the decision (or not) to start production in the organic system before obtaining organic certification in the United States of America. They noted that the producers did not intend to certify their production, since they traded on direct channels it was not necessary to certify it. Small producers who marketed in their municipalities, using channels such as fairs, home delivery and sale on the property, would not be motivated to remain certified, or even certify their production system.

Gambelli et al. (2014) tried to point out the risk of non-compliance in relation to fulfillment of organic certificate by producers in Italy and Germany and they demonstrated that the probability of this event increases due to several factors: property's growth (especially in Italy); producing properties of vegetables, swine and cereals; further expertise (with respect to time) with the certification agency (in Germany only). The authors did not address other factors as risk probability of non-compliance with the certification, such as age of the producer, historical criminal record and ability to pay, but they believe that such factors could also be significant for analysis. The authors themselves point out problems in their study because they did not consider the financial aspects of the producers neither the personal characteristics.

In this sense, Brito (2016) compared financial viability between conventional and organic mango production in the São Francisco Valley. According to the author, the initial costs in organic production are higher as a result of the process of conversion to certification that is submitted to rural property when adhering to organic cultivation; however, some factors indicate that organic production is more financially and economically viable than conventional farming, 
as a result of higher selling prices and return on investment in organic production to be faster than the return in conventional agriculture.

Some research developed in Brazil deal with the certification systems used, as well as difficulties faced by the rural producers who produce in agro-ecological based production systems. The study carried out with farmers from a rural settlement of Chapadinha, Distrito Federal - Brazil, through a case study with eight settlers who were in the process of obtaining the declaration issued through an SCO for the production and sale of organic products, pointed out the difficulty of producers in the understanding of the standards for certification, as explained in this article, namely Law no 10831 of 2003, Decree no 6323 of 2007 and Normative Instruction 46 of 2011.

Although producers meet the requirements for production and marketing of organic products, they are unaware of the bureaucratic issues involved in the certification process, from knowledge of standards to records procedures that are not performed. In this settlement, there are 42 settlers, of whom 23 obtained the declaration for direct sale of organic products (MUÑOZ et al., 2016). Furthermore, as Niederle (2014) points out, the requirements related to organic management practices are restricted and do not extend to traditional knowledge practices, which often leads to difficulties in adapting farmers to the certified system.

For Meira and Candiotto cited by Vriesman et al. (2012), certification systems should be flexible and adaptable to the reality of Brazilian family farmers. The organization of farmers (association or cooperative) is fundamental for the expansion of the organic movement and is necessary to overcome financial and technological obstacles of rural properties, such as the certification process, and easy access to resources for the production and marketing of products. In addition, it is worth highlighting the need for the constant monitoring of the producers done by the extension agents who are responsible for the technical information, updating the standards and recording the problems.

As mentioned before, the certification process as well as its maintenance involve a range of factors that may lead to the producer's dropout of the certified system. Costs to certify and maintain the certificate, difficulties in understanding and complying with organic production standards for obtaining and maintaining the certificates, channel used for the spreading of their products are some of the reasons that may lead the producer to give up organic production in the system certificate.

\subsection{Organic products in Brazil and their certified production systems benefits}

According with Ifoam and FIBL report (2014), Brazil had in 2013 a total of 705,233 hectares of land for organic production, with 12,526 producers. The number of certified agricultural holdings in organic production grew slightly, especially in the extension of agricultural land, since in 2015 there were 12,655 producers on 750,000 hectares of land (IFOAM and FIBL, 2017). Estimates made in the Ifoam and IFBL (2015) report were that by the end of 2015 there would be 50,000 producers with organic certification. This number is not reached according to the data from the 2017 report. It is a fact that public policies have been developed to promote agroecological agriculture in Brazil, such as Planapo (National Plan for Agroecology and Organic Production), which aims to expand and implement actions for sustainable development, involving family agriculture and social groups such as rural women, quilombolas and rural youth.

Organic food production systems bring social, environmental, economic and health benefits. The consumption of products produced in this type of system has evolved in an expressive way since consumers relate the negative effects of the intensive conventional agricultural production systems, the positive effects of organic agroecological production systems and the direct impact they both have on their health (VRIESMAN et al.,2012). In 2015 the consumption of organic products in Brazil reached a growth rate of $25 \%$ (Organicsnet), following a worldwide trend of increasing demand for products and services that provide health and well-being, according to Dias et al. (2015). In addition, organic production systems contribute effectively to environmental, economic and social markets.

According to Altieri (2004), the use basic agroecological production systems contributes to agricultural productivity, while seeking preservation of the ecosystem. The effects of implementing these practices are many. From improvement in the physical, chemical and biological quality of the soil, 
to the reduction of pests and diseases by balancing the biodiversity of the system to production stability and independence from external resources (inputs, pesticides etc).

In Brazil, the family farmer group is the most representative in organic production (about 90\% (IBGE, 2006)). In this sense, it can be said that besides contributing to the biodiversity of agricultural systems preserving the resources of the environment, organic agriculture also contributes to the permanence of family farmers in the field. They produce their products using the natural resources in order to preserve such biodiversity in an endogenous manner without the dependence of external inputs, which enables this activity with improved income to the producer (VRIESMAN et al., 2012).

It should be emphasized that the economic side has interesting characteristics to be analyzed in relation to organic farming compared to conventional ones. Environment degradation (soil, water and other natural resources) such as erosion, deterioration and contamination of rivers is not accounted for when the financial analysis of the properties is sustained. Altieri (2004) argues that such elements, which he calls "natural accounting", should be incorporated into the financial analysis since the distribution of the ecosystem requires high resources for its recovery. In addition, agricultural practices that reduce or prevent environmental degradation are financially more rewarding for rural activity from this perspective in natural accounting.

Although organic certification offers numerous benefits to producers and ensures the quality of organic food to consumers, the high amount of documentation and bureaucracy to meet all requirements imposed by its legislation and certification, coupled with poor technical assistance, may lead the producer to give up certification.

\section{Materials and methods}

This is an exploratory research with a quantitative approach. According to Gil (1999), an exploratory research has as its main objective to develop, clarify and modify concepts and ideas in order to the formulation of problems and searchable hypotheses for further studies. This type of research is carried out when the subject matter is unexplored and it's difficult to provide accurate and actionable hypotheses about it. Particularly, for this research, this method is the most appropriate since this theme (determining factors for the continuity of the organic producer into certified activity) is a matter practically unexplored.

For data acquisition and scientific treatment the quantitative approach was chosen. This approach is characterized by the use of quantification, both in information collection modalities, as to the treatment of them by means of statistical techniques (RICHARDSON, 2008).

Data have been collected at the end of 2012 and throughout 2013 through organizations related to organic food production in Brazil, such as organic producers associations and certification agencies of organics, by means of private certifying agencies or through associations that performed the evaluation of participative compliance. At referred period there were eleven capable agencies (certified by MAPA) to conduct the compliance assessment in Brazil. Among these agencies, it was not possible to obtain contacts data of the producers in three: a certifying agency and two associations that performed participatory certification. It is noteworthy that producers who are registered by means of social control agencies were not part of this research once they are not required to have a certificate of compliance assessment of organic production, as foreseen in the Brazilian official regulation.

Thus, from the database of these certification agencies, a data collection was conducted using the survey as a research method. The data collection instrument used in this study was a questionnaire with closed multiple choice questions. This was applied by email, by post and through in-person or telephone interviews with 900 farmers with the organic production certificate in Brazil, of whom $200(22.2 \%)$ agreed to participate and completed the survey. Having in mind that the sample was selected in a haphazard manner, i.e., was composed only by producers who agreed to participate in the survey it is not representative of the population of certified producers in Brazil. But in exploratory studies, as in this case, the representativeness of the sample becomes a secondary concern, since the purpose is to analyze a phenomena and not extrapolate the results to the population (CHURCHILL, 1999). It was not possible to access producers with properties that no longer 
have the organic production, since the certifying body did not provide complete contact information for all producers and thus the sample stratum of these producers would very small. Thus, the focus was given to producers whose properties are certified, which does not invalidate the research, as the opinion of the producers is extremely important for action to maintain and strengthen the organic production sector in Brazil.

The questionnaire was composed by 16 variables (assertive), coded from V1 to V16, as shown in Table 1. Each variable covers a reason for the non-renewal of organic production certification and corresponded to a Likert scale of five points (had no influence, had minor influence, had influence, had major influence, had great influence). For these answers the values $1,2,3,4$ and 5, respectively, were assigned. The respondents stationed themselves in each of the 16 variables, indicating the possible points of this scale. The process of creating these variables took place from initial impressions of the object of study, informal conversations, as well as articles relating to the organic sector. It is emphasized that was not found in the international literature articles related to this topic.

Data were first analyzed using descriptive statistics (tables, charts and descriptive measures) and then, using multivariate analysis technique based on Exploratory Factorial Analysis (EFA). All analyzes were performed using SPSS software (IBM, 2013).

\subsection{Exploratory Factorial Analysis}

Factorial Analysis (FA) is used when there are a lot of variables correlated to each other based on the assumption that the correlation between the variables arises because they share or are related by the same factor. Therefore, the objective of FA is to identify factors that are not directly observable (latent variables) through the correlation between a set of observables variables that can be measured (CORRAR et al., 2009).

In this study we used Exploratory Factorial Analysis (EFA), which is characterized by not requiring previous knowledge of the dependency relationship between the variables under study. The EFA analyzes understands and identifies a relationship structure between these variables.

At EFA we seek to minimize the number of variables included, however, we should maintain a reasonable number of variables by factor, avoiding factors composed by a single variable. As a general rule, the sample size (or the number of observations) should be at least five times greater than the number of variables to be analyzed (HAIR et al., 2006). Hence in this work the minimum criteria of observations has been respected.

The procedure for EFA can be described as:

1. Mathematical model of Cronbach's Alpha: Coefficient based on the average correlation

Table 1. Research variables (assertive)

\begin{tabular}{cl}
\hline $\begin{array}{c}\text { Varibale Identification } \\
\text { Code }\end{array}$ & \multicolumn{1}{c}{ Questions related to no-renewal of certification } \\
\hline V1 & Difficulties of understanding and comprehension of the rules of organic production \\
V2 & Difficulties to meet the production standards under the law \\
V3 & Difficulties to produce organic with conventional \\
V4 & Incorrect execution of the practices by workers \\
V5 & Investments in infrastructure, worker safety, worker training \\
V6 & No stamp required \\
V7 & Distance to the consumer \\
V8 & Certification costs \\
V9 & Lack of trust with the certifier \\
V10 & High prices of inputs \\
V11 & lack of information about inputs \\
V12 & No differentiation perceived by the consumer of the organic product compared to conventional one \\
V13 & Low regularity in customer orders \\
V14 & There is no contract to supply products to customers \\
V15 & No fulfillment of requirements for maintaining the certificate \\
V16 & Lack of orientation regarding the not reached certification requirements \\
\hline
\end{tabular}

Source: Prepared by authors. 
between items. It is about an analysis of the measurement scales, checking the reliability of the construct dimensions or the real impact of latent random variables. This coefficient varies between 0 and 1 , and the closer it is to 1 , greater is the reliability (CORRAR et al. 2009). According to Hair et al. (2006), the ideal minimum value for Cronbach's Alpha is 0.7 for applied surveys and 0.6 for exploratory ones.

2. Calculation of the correlation matrix: It is a matrix that shows the simple correlations between all possible pairs of variables analyzed. The measures for sampling adequacy (or assessment of the adequacy EFA) are: a) Measure of Kaiser-Meyer-Olkin (KMO) - varies between 0 and 1 by checking the degree of partial correlation among the variables. If $\mathrm{KMO}>0.6$ is possible to use EFA, and the closer to 1 much the better it will be; b) Bartlett test of spherical shape - which examines the hypothesis that the population correlation matrix is an identity matrix (zero correlation between variables). If $\mathrm{p}_{-}$value $\leq \infty$, then it can be concluded that the model EFA is suitable for data processing; c) The antiimage correlation matrix - which indicates the explanation power of the factors for each variable analyzed. This matrix shows in its diagonal the value of the sample adequacy measurement for each variable and in other fields the partial correlation (CORRAR et al. 2009). In this work, the main diagonal values lower than 0.50 were considered not significant, indicating variables which could be drawn from the analysis; d) Commonality matrix - which indicates the ratio of the variance that a variable shares with all other variables considered, or even is the proportion of variance explained by common factors. In this work, commonality values lower than 0.50 also were considered not significant, indicating variables which could be drawn from the analysis.

3. Extraction of factors: There are numerous methods for the extraction of factors in literature, such as key components, key factors, factorization by imaging, factorization by maximum likelihood estimation, alpha factorization, least squares, etc. In order to obtain a reduction of data, the method based on Principal Component Analysis (PCA) was chosen. This method seeks for a linear combination of variables, so that the maximum variance can be explained by this combination. Then, the previously explained variance is removed and there is a search for a new linear combination of variables that explains the biggest remaining amount of variance and so on (JOHNSON and WICHERN 1992). This procedure results in orthogonal factors, i.e., are not correlated with each other. Thus, the number of factors were chosen by the Kaiser criteria, i.e., only the factors with eigenvalues (total variance explained by each factor) above one were extracted.

4. Rotation of factors: There are two types of rotation (orthogonal and oblique) to obtain the mathematical model that rotates the axes in the geometric space and determines which variables are loaded into which components. Both, generally, present similar results. In orthogonal rotations must be assumed that the factors are independent, however, they are easier to describe and interpret. The oblique rotations allow that factors are related, but they are more complex to describe and interpret (TABACHINICK and FIDELL, 2007). In this work the Varimax orthogonal rotation method with Kaiser normalization was chosen. This method is the most commonly used in literature and seeks to minimize the number of variables that have high loads (simple correlations between variables and factors) in each factor.

5. Calculation of scores: Scores are estimated components of each observation (organic producer certified) in the derivative factors. The scores coefficient matrix has values that, when multiplied by the original values of the variables, give rise to latent indicators or simply factorial scores. 


\section{Results and discussion}

Producers with organic production certification in Brazil who answered to this survey have the state distribution described in Figure 1 and the area distribution described in Table 2. It can be observed that most of the respondents producers are from the states of São Paulo, Rio Grande do Sul, Goiás and Santa Catarina, respectively. Regarding to the area of properties, the vast majority $(91 \%)$ has up to 100 hectares.

Table 2. Distribution of surveyed producers by area (in hectares)

\begin{tabular}{l|c}
\hline under $\mathbf{1 0}$ ha & $43.00 \%$ \\
\hline $\mathbf{1 0}$ - $\mathbf{1 0 0}$ ha & $48.00 \%$ \\
\hline $\mathbf{1 0 0}$ - $\mathbf{3 0 0 h a}$ & $5.00 \%$ \\
\hline above $\mathbf{3 0 0}$ ha & $4.00 \%$ \\
\hline
\end{tabular}

Source: Prepared by authors.

First, the studied variables were analyzed descriptively. Table 3 shows that the variables considered the most influential in non-renewal of organic production certification, according to certified producers were: V8 (certification costs),
V10 (high prices of inputs), V11 (lack of information on the appropriate inputs), V6 (no stamp required), V7 (distance to the consumer) and V12 (no differentiation perceived by the consumer of the organic product compared to conventional one), respectively, which presented the highest means and medians relative to the other, since all the modes match. In contrast, the variables considered of minor influence were: V9 (lack of trust with the certifier) and V16 (lack of orientation regarding the not reached certification requirements), respectively.

Next, a reliability analysis of the construct composed of 16 questions used to obtain the data was carried out. In accordance with the Cronbach's Alpha model, internal reliability is 0.899 . Therefore, the questions are suitable for the purpose for which they are designated.

Thus, according to Table 4, the final EFA (after three attempts) resulted in a KMO coefficient of 0.851 . As a result, the data adjustment degree to the EFA is above the level of 0.6 that is a limiting factor in application of this technique. The spherical shape test also resulted in a probability of significance below the level of significance adopted $(\infty=0.05)$, once again confirming the suitability of the EFA to the data. Table 4 also shows

Figure 1. Distribution of surveyed producers by state

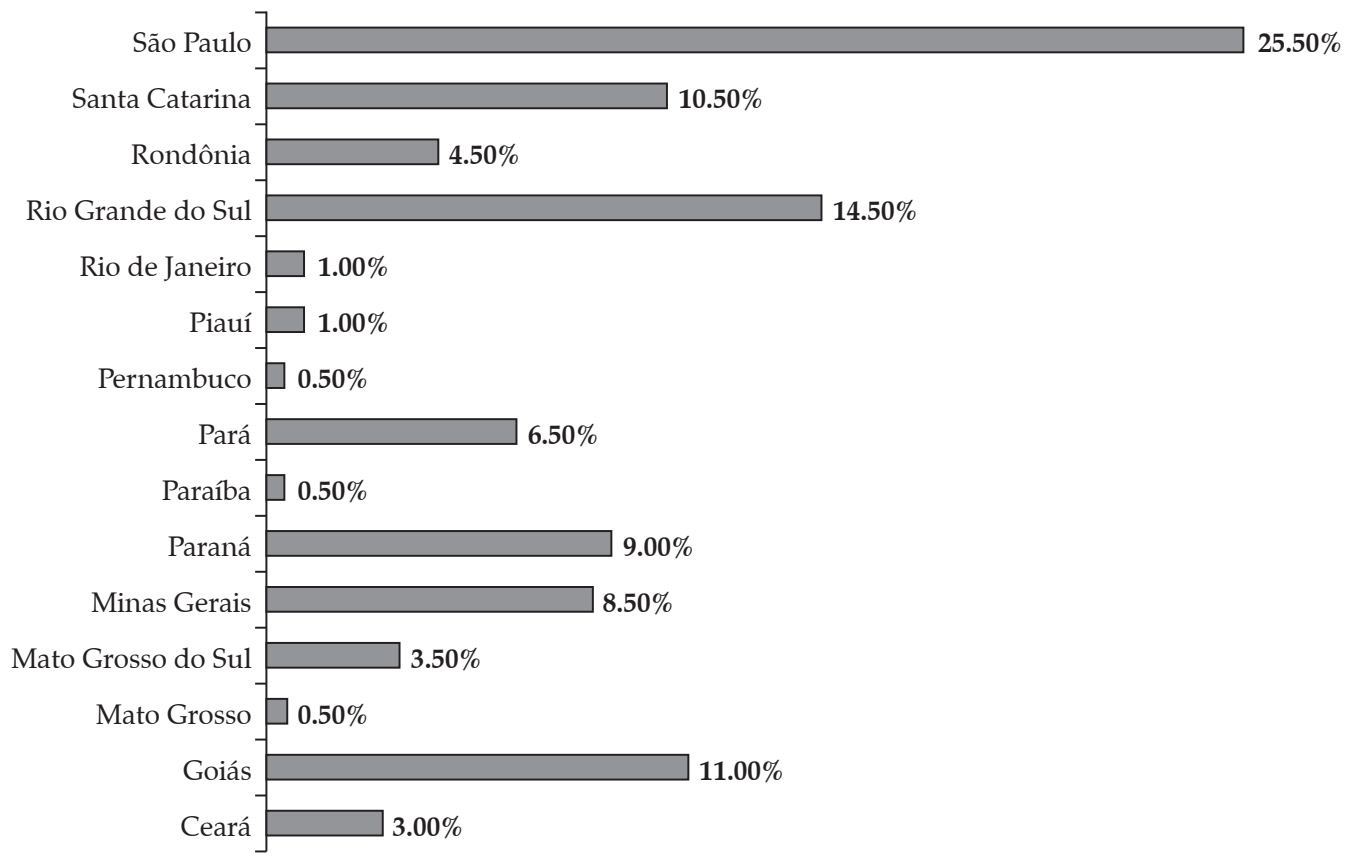

Source: Prepared by authors. 
that the commonalities for variables selected by FA are between 0.547 and 0.827 . Furthermore, the anti-image correlation matrix for these variables were between 0.792 and 0.902 . For both cases the values are above 0.5 , confirming the importance of selected variables for the formation of the factors. Also according to
Table 4, the total variance of the data can be explained by three factors (extracted by the Kaiser method), since these factors correspond to approximately $70 \%$ of this variance. The values obtained shall be considered satisfactory, allowing a deepening in the analysis of the factors generated by EFA.

Table 3. Descriptive measures

\begin{tabular}{ccccc}
\hline Variable & Mean & Median & Mode & Standard Deviation \\
\hline V1 & 1.8 & 1 & 1 & 1.11 \\
V2 & 1.9 & 2 & 1 & 1.09 \\
V3 & 1.8 & 1 & 1 & 1.09 \\
V4 & 1.8 & 1 & 1 & 0.99 \\
V5 & 1.9 & 2 & 1 & 0.99 \\
V6 & 2.2 & 1.5 & 1 & 1.42 \\
V7 & 2.1 & 2 & 1 & 1.24 \\
V8 & 2.2 & 2 & 1 & 1.21 \\
V9 & 1.5 & 1 & 1 & 0.90 \\
V10 & 2.2 & 2 & 1 & 1.15 \\
V11 & 2.2 & 2 & 1 & 1.24 \\
V12 & 2.1 & 2 & 1 & 1.17 \\
V13 & 2.0 & 2 & 1 & 1.15 \\
V14 & 1.9 & 1 & 1 & 1.25 \\
V15 & 1.7 & 1 & 1 & 1.06 \\
V16 & 1.6 & 1 & 1 & 1.03 \\
\hline
\end{tabular}

Source: Prepared by author.

Table 4. Summary of Factor Analysis

\begin{tabular}{|c|c|c|c|}
\hline \multicolumn{4}{|l|}{ Measures of Suitability } \\
\hline Kaiser-Meyer-Olkin (KMO) & & & ,851 \\
\hline \multirow{3}{*}{ Bartlett's test sphericity } & \multicolumn{2}{|c|}{ Chi-square } & 1053,506 \\
\hline & \multicolumn{2}{|c|}{ Degrees of freedom } & 55 \\
\hline & \multicolumn{2}{|c|}{ p_value } & ,001 \\
\hline \multicolumn{4}{|c|}{ Commonality (Extraction Method: Principal Component Analysis) } \\
\hline Variable & \multicolumn{2}{|c|}{ Initial } & Extraction \\
\hline V1 & \multicolumn{2}{|c|}{1,000} & ,827 \\
\hline $\mathrm{V} 2$ & \multicolumn{2}{|c|}{1,000} & 817 \\
\hline V6 & \multicolumn{2}{|c|}{1,000} & 600 \\
\hline V7 & \multicolumn{2}{|c|}{1,000} &, 598 \\
\hline V10 & \multicolumn{2}{|c|}{1,000} & 678 \\
\hline V11 & \multicolumn{2}{|c|}{1,000} & 638 \\
\hline V12 & \multicolumn{2}{|c|}{1,000} &, 547 \\
\hline V13 & \multicolumn{2}{|c|}{1,000} & 670 \\
\hline V14 & \multicolumn{2}{|c|}{1,000} & ,714 \\
\hline V15 & \multicolumn{2}{|c|}{1,000} & 769 \\
\hline V16 & \multicolumn{2}{|c|}{1,000} & ,776 \\
\hline \multicolumn{4}{|l|}{ Total Variance Explained } \\
\hline \multirow{2}{*}{ Component } & \multicolumn{3}{|c|}{ Eigenvalues } \\
\hline & Total & Variance $\%$ & Accumulated \% \\
\hline 1 & 5,044 & 45,851 & 45,851 \\
\hline 2 & 1,567 & 14,244 & 60,095 \\
\hline 3 & 1,023 & 9,304 & 69,399 \\
\hline
\end{tabular}

Source: Prepared by authors. 
Table 5. Rotated Component Matrix

\begin{tabular}{|c|c|c|c|}
\hline \multirow{2}{*}{ Variable } & \multicolumn{3}{|c|}{ Component } \\
\hline & 1 & 2 & 3 \\
\hline V16 & ,798 & & \\
\hline V15 & 793 & & \\
\hline V14 & ,789 & & \\
\hline V13 & ,747 & & \\
\hline V10 & & 792 & \\
\hline V6 & & ,767 & \\
\hline V7 & & 707 & \\
\hline V11 & & 640 & \\
\hline V12 & &, 556 & \\
\hline V1 & & & ,862 \\
\hline V2 & & & ,824 \\
\hline$\%$ of explained variance by each factor (rotation) & 25,547 & 24,941 & 18,911 \\
\hline Cronbach'alpha & 0,844 & 0,811 & 0,845 \\
\hline \multicolumn{4}{|l|}{ Extraction method: Principal Component Analysis } \\
\hline Rotation Method: Varimax with Kaiser Normalizati & & & \\
\hline
\end{tabular}

Thus, the EFA resulted in three determining factors for the possible non-renewal of organic production certification. As shown in Table 5, the first factor brings together variables V16, V15, V14 and V13 (transactions). The second factor brings together variables V10, V6, V7, V11 and V12 (organization of the supply chain). And the third sector brings together V1 and V2 variables (regulation). Cronbach's Alpha model also shows that items (or variables) that compose each factor have acceptable internal reliability.

Considering that the factors can be represented by the linear relationship between the variables, then, these determining factors for non-renewal of certification can be expressed by the following equations:

$F 1=0.798 V 16+0.793 V 15+0.789 V 14+$ $0.747 V 13$

$$
F 2=0.792 \mathrm{~V} 10+0.767 \mathrm{~V} 6+0.707 \mathrm{~V} 7+
$$$$
0.640 V 11+0.556 V 12
$$$$
F 3=0.862 V 1+0.824 V 2
$$

Therefore, according to developed EFA, the possibility of non-renewal of organic production certification in rural properties results from the following order of relevance of the factors:

1. The first factor - F1 - can be called "transactions". It consists of variables associated with the establishment of contracts and trading with customers, as well as aspects related to negotiations transactions with certifying agencies (failure to meet the certification requirements and lack of orientation of this regarding not fulfilled requirements). This factor explains about $25.5 \%$ of the data variance. It is considered that the failure to meet the requirements to stay with the certificate (V15) leads the producer to the need for adjustments in their production process, which should be held in deadlines set by the certifier. Thus, the lack of orientation of the certifying agencies (or PAS) with respect to this need (V16), can lead to non-renewal of certificate, generating conflicts between producer and certifier. For these reasons, that transaction (producer-certifier) was identified as a determining factor for the non-renewal of certificate.

2. The second factor - F2 - can be called "organization of the supply chain". It consists on variables that indicate the lack of information and the high costs relating to inputs (the upstream of the chain), as well as aspects related to the downstream of the chain, such as the low importance of the stamp to the consumer (considered by producer), and the long distances for the customer market. This factor accounts for approximately $24.9 \%$ of total variance. 
3. The third factor-F3-can be called "regulation". It consists of variables relating to the difficulty in understanding the rules, as well as difficulty in meeting these rules. This factor explains nearly $18.9 \%$ of the data variance.

It should be noted that most of the variables that were highlighted by producers as variables that influence the non-renewal of certification (in the descriptive analysis) were significant in EFA. These are represented in the first two factors, such as variables V6, V7, V10, V11, V12 and V16, except for V8 and V9. The V1 and V2 variables that refers to the "regulation" factor were not identified in descriptive analysis, however, have been considered in EFA. Although not considered in EFA, V8 variable (high cost for the renewal of the certificate) was considered in the descriptive analysis as an influential factor for decision of non-renewal of the certificate. Such verification corroborates to the survey of Pietola and Lansink (2001) and Brito (2016), in which producers pointed as decisive in no conversion from conventional to organic system or to difficulty in maintaining the certification. Furthermore, one of the variables of factor 1 in EFA refers to the conflicts in the negotiations between producer and certifier, being the cost of certification one relevant element in these negotiations.

Even though limited number of studies related to this topic, the results of this research corroborate with some research concerning the difficulty of rural producers into staying in certified organic activity. Flaten et al. (2010) as well as Dullley et al. (2003), Sierra et al. (2008) e Muñoz et al. (2016) indicate the "regulation" as one of the main factors that would lead Norwegian rural producers to leave certified organic activity. Such verification was done also in this survey with Brazilian producers, since the EFA indicated as the third factor in order of importance. MacInnis (2004) pointed out the lack of trade channels for organic products as a barrier to adherence to the organic system. In this research it was observed that, regarding the factor "organization of the supply chain", the aspects related to the distance between producer and consumer is one of the variables that can compromise the permanence of the producer in organic agriculture, since the producers often opt for marketing their products in short chains (MUNOZ et al., 2016). In this case, the third-party or participative certification is unnecessary. However, it is emphasized that the producer needs to submit to the supervision of a SCO.

\section{Conclusions and proposed actions}

With the achieved results, it can be concluded that there are certain factors that contribute to the uncertainty of producers concerning their permanence in certified activity. This is due to the fact that the certification process and the regulation of organic sector in Brazil is still recent. Examples of these factors are the difficulties of understanding the rules for organic production as well as the difficulties to meet these rules.

Since this is a sector at the beginning of consolidation process in Brazil, several challenges still need to be surpassed, once that there are no warranties to the producer in flowing out their production; the possibility of non-compliance for certificates requirements; as well as lack of orientations from certifying agencies regarding the requirements not fulfilled (even if this is not the role of certifier) leads to uncertainty of the producer to remain in the certificate system. Additionally, the lack of organization of the supply chain, both in the upstream, in which there is no information regarding inputs that can be used and with unworkable prices to the producer, as well as in downstream, due to the poor dissemination and, consequently, consumer misinformation in identifying what is indeed an organic product.

Thus, some actions proposed that might contribute to reducing uncertainties regarding certification are:

- Promoting institutional marketing to consumers through representative class entities of the sector in order to clarify for consumers in respect to differences of organic against conventional product. Emphasizing that the characteristics extend beyond consumption of organic products (without pesticides) emphasize that the production of these products contributes to the improvement of the quality of the environment in general, preserving areas of permanent forest reserves, native vegetation and watersheds. Besides the promotion of organic stamp, which is still unfamiliar by Brazilian consumers.

- Encouraging public policies to stimulate the production of inputs suitable for organic 
agriculture, mainly seeds, since ones that exist currently on the market are unable to fulfill with quality the required demand and are still unreachable to producers due to the high costs.

- Closer proximity of certifiers and producers within the meaning of assistance to producers to understand and apply the certification rules. It is known that the certifier, as a third-party during the certification process, should not have any relationship with the producer in order to ensure greater transparency and fairness in the certification process. However, the guidelines (notes) of the mistakes made by producers are essential so that they can make the necessary adjustments. It is suggested therefore that the certifier could help the producer in order to contribute to the producer can fulfill the requested requirements. Besides the certifier, class entities such as associations of producers, are also relevant stakeholders to producers and should promote actions that could contribute to their members for a deeper understanding of the rules and hence the compliance with them.

- Promoting actions so that the associations and cooperatives of producers are stimulated to convert to the organic system by means of public politics and open space for the participative certification in reason of the costs involved in the third-party certification or by means of an audit.

- Capacitating the extensions agents for the assistance and guidance to producers in transition to the organic system, as well as those who have already obtained the organic certificate to update the technical information.

It is worth mentioning that information about producers that have abandoned or have lost organic certification are kept confidential by the agencies in Brazil. This fact prevented the comparative study between the producers who maintain the certification and those who do not maintain. Even though, this research reached its proposal.

\section{References}

ABNT - Associação Brasileira de Normas Técnicas, Programa de capacitação de recursos humanos em normalização, unidade 1.4 - noções básicas de avaliação de conformidade, 2008.

NBR ISSO/IEC 17000: avaliação de conformidade: vocabulário e princípios gerais. Rio de Janeiro, 2005.

ALTIERI, M. Agroecologia: a dinâmica produtiva da agricultura sustentável. UFRGS, 5. ed., 118p, 1998.

BRASIL. Instrução Normativa № 007, de 17 de maio de 1999.

BRASIL. Decreto lei № 10.831, 23 de dezembro de 2003.

BRASIL. Decreto lei № 6.323, 27 de dezembro de 2007.

BRASIL. Decreto lei № 7.048, 23 de dezembro de 2009. Disponível em: <http://sistemasweb.agricultura.gov. $\mathrm{br} /$ sislegis/action/detalhaAto.do?method=consultarLe gislacaoFederal>. Acesso em: 2011.

BRASIL. Ministério da Agricultura, Pecuária e Abastecimento. Número de produtores orgânicos cresce 51,7\% em um ano, 2015. Disponível em: < http:// www.agricultura.gov.br/comunicacao/noticias/2015/03/ numero-de-produtores-organicos-cresce-51 porcentoem-um-ano >. Acesso em: 20 mar. 2015.

BRITO, W. S. F. Custos e viabilidade financeira da agricultura orgânica versus agricultura convencional: o caso da manga no vale do são Francisco, Anais do Congresso Brasileiro de Custos. Porto Seguro, BA: 27 a 30 de outubro de 2004.

CORRAR, L. J., PAULO, E. and DIAS FILHO, J. M. Análise multivariada. FIPECAFI: Atlas, 2007.

CHURCHILL JR., G. A. Marketing research: methodological foundations. Orlando: Dryden Press, 1999.

DIAS, V. V. et al. O mercado de alimentos orgânicos: um panorama quantitative e qualitative das publicações internacionais. Ambiente \& Sociedade, São Paulo, v. XVIII, n. 1, p. 161-182, 2015.

DULLEY, R. D., SILVA, V. and ANDRADE, J. P. S. Estrutura produtiva e adequação ao sistema de produção orgânico. Informações Econômicas, São Paulo, v. 33, n. 11, 2003.

FLATEN, O. et al. Comparing risk perceptions and risk management in organic and conventional dairy farming: empirical results from Norway. Livestock Production Science, v. 95, p. 11-25, 2005.

GAMBELLI et al. Non-compliance in organic farming: a cross-country comparison of Italy and Germany. Food Policy, n. 49, p. 449-458, 2014. 
GIL, A. C. Métodos e técnicas de pesquisa social. 5. ed. São Paulo: Atlas, 1999.

HAIR JR., J. F. et al. Multivariate data analysis. Upper Saddle River, NJ: Pearson Prentice Hall, 2006.

IBGE. Censo agropecuária. Disponível em: <http:// www.ibge.gov.br/home/estatistica/economia/ agropecuaria/censoagro/default.shtm > . Acesso em: 17 mar. 2017.

IBM Corp Released. IBM SPSS Statistics for windows. Version 22.0. Armonk. New York: IBM Corp, 2013.

IFOAM e FIBL. Research Institute of Organic Agriculture. Organic world. Global organic farming statistics and news. Data tables FiBL-IFOAM, 2014. Disponível em: <http://www.organic-world.net/ statistics-fao.html> . Acesso em: 28 abr. 2014.

Research Institute of Organic Agriculture. Organic world. Global organic farming statistics and news. Data tables FiBL-IFOAM, 2015.

Research Institute of Organic Agriculture. Organic world. Global organic farming statistics and news. Data tables FiBL-IFOAM, 2016. Disponível em: <https://shop.fibl.org/fileadmin/documents/shop/1698organic-world-2016.pdf> . Acesso em: 24 fev. 2017.

Research Institute of Organic Agriculture. Organic world. Global Organic farming statistics and news. Data tables FiBL-IFOAM, 2017. Disponível em: <https://shop.fibl.org/fileadmin/documents/ shop/3503-organic-world-2017.pdf $>$. Acesso em: 17 mar. 2017.

JOHNSON, R. A. and WICHERN, D. W. Applied multivariate statistical analysis. Englewood Cliffs: Prentice Hall, 1992.

MACINNIS, B. Transaction costs and organic marketing: evidence from U.S. organic produce farmers. Selected Paper Prepared for Presentation at the American Agricultural Economics Association Annual Meeting, Denver, CO. Aug 1 - Aug4, 2004.

MAPA. Ministério da Agricultura, Pecuária e Abastecimento: mecanismos de controle de qualidade orgânica. Disponível em: <http://www.prefiraorganicos.com. br/agrorganica/mecanismosdecontrole.aspx $>$. Acesso em: 14 jul. 2011.

MUÑOZ,C.M.G.etal. Normativa de produção orgânica no Brasil: a percepção dos agricultores familiares do assentamento de Chapadinha, Sobradinho (DF). RESR, v. 24, n. 2, p. 361-376, abr./jun. 2016.

ORGANICSNET. Mercado de orgânicos cresce o dobro no Brasil, 2016. Disponível em: < http://www.organicsnet. com.br/2016/01/mercado-de-organicos-cresce-odobro-no-brasil/>. Acesso em: 8 mar. 2016.

PIETOLA, K. e LANSINK, A. Farmer response to policies promoting organic farming technologies in Finland. European Review of Agricultural Economics, v. 28, p. 1-15, 2001.

RICHARDSON, R. J. Pesquisa social - métodos e técnicas. 3. ed. São Paulo: Atlas, 2008.

SIERRA, L. et al. Factors associated with deregistration among organic farmers in California. Davis, CA: California Institute for Rural Studies, mar. 2008. Disponível em: <http://169.237.124.167/Organic/ reports/2008_Deregistration_factors.pdf $>$.

SOUZA, A. P. de O. and ALCÂNTARA, R. L. C. Alimentos orgânicos: estratégias para o desenvolvimento do mercado. In: NEVES, M. F. and CASTRO, L. T. (Orgs.). Marketing e estratégia em agronegócios e alimentos. São Paulo: Atlas, 2003. 365 p.

SOUZA, M. C. M. de. Certificação de produtos orgânicos. Disponível em: <http://www.iea.sp.gov.br/out/ verTexto.php?codTexto $=260>$. Acesso em: 14 jul. 2011.

TABACHNICK, B. and FIDELL, L. Using multivariate analysis. Needham Heights: Allyn \& Bacon, 2007.

VELDSTRA, M. D., ALEXANDER, C. E. and MARSHALL, M. I. To certify or not to certify? Separating the organic production and certification decisions. Food Policy, v. 49, P2, p. 429-436. http://doi. org/10.1016/j.foodpol.2014.05.010, 2014

VRIESMAN, A. K. et al. Assistência técnica e extensão rural para a certificação de produtos orgânicos da agricultura familiar. Revista Conexão UEPG, v. 8, n. 1, p. 138-149, 2012. 